\title{
PENGARUH LIKUIDITAS DAN PROFITABILITAS TERHADAP HARGA SAHAM PADA PERUSAHAAN FOOD AND BAVERAGES YANG TARDAFTAR DI BURSA EFEK INDONESIA TAHUN 2016-2019
}

\author{
Mike Stevenson Tokoro ${ }^{1}$ \\ mikestevensontokoro06@gmail.com \\ Miratul Hasanah ${ }^{2}$ \\ m.hasanah@gmail.com \\ 1-2 Jurusan Manajemen Fakultas Ekonomi dan Bisnis Universitas Cenderawasih
}

\begin{abstract}
Abstraksi:
Penelitian ini bertujuan untuk menguji dan mengetahui pengaruh Likuiditas, Solvabilitas, Dan Profitabilitas secara parsial dan simultan terhadap harga saham pada perusahaan Food and Baverages yang Terdaftar di Bursa Efek Indonesia Periode 2016-2019.Penelitian ini menggunakan pendekatan kuantitatif. Sampel yang digunakan dalam penelitian ini berjumlah 8 perusahaan. Sumber data yang digunakan adalah data sekunder dengan teknik pengumpulan data yaitu studi kepustakaan dan teknik dokumentasi. Yang kemudian dianalisis menggunakan analisis regresi linear berganda menggunakan bantuan software SPSS. Hasil penelitian ini menunjukkan bahwa secara parsial Likuiditas (Current Ratio) dan Profitabilitas (Return On Asset) berpengaruh signifikan terhadap harga saham, sedangkan Solvabilitas (Debt To Equity Ratio) tidak berpengaruh signifikan terhadap harga saham. Secara simultan Current Ratio, Debt To Equity Ratio dan Return On Aset berpengaruh signifikan terhadap harga saham. Pengaruh Current Ratio, Debt To Equity Ratio dan Return On Aset terhadap harga saham sebesar 63.8\%.
\end{abstract}

Kata Kunci: Likuiditas, Solvabilitas, Profitabilitas, dan Harga Saham

\section{PENDAHULUAN}

\section{A. Latar Belakang}

Suatu perkembangan dan kesuksesan perusahaan-perusahaan yang ada dipengaruhi oleh pertumbuhan ekonomi di dalam Negara. Untuk memperoleh laba atau keuntungan dengan jumlah yang sebesar-besarnya agar dapat terus berjalan (going concern) adalah salah satu tujuan utama perusahaan. Dengan meningkatkan nilai perusahaan, kemakmuran perusahaan dan harga sahamnya yaitu salah satu tujuan utama perusahaan. Ketika suatu perusahaan memutuskan untuk berkembang, maka perusahaan tersebut akan meningkatkan kinerja dan inovasi produknya sehingga membutuhkan modal yang tidak sedikit. Salah satu cara perusahaan untuk memenuhi kebutuhan dananya yaitu dengan cara menjual sahamnya dipasar modal yang anggap sebagai go public, (Aryani dan Zulkifli, (2016).

Semakin bertambahnya jumlah perusahaan Food and Baverages yang terdaftar di Bursa Efek Indonesia hal tersebut dapat dilihat dengan berbagai perusahaan industri manufaktur khususnya pada sektor makanan dan minuman (Food and Baverages) kini semakin berkembang pesat di Indonesia. Food and Baverages adalah Perusahaan yang memproduksi berupa makanan dan minuman yang pada umumnya menjadi kebutuhan masyarakat, dan merupakan Salah satu sektor perusahaan yang banyak diminati oleh investor untuk menanamkan modal atau saham.

Keadaan ekonomi yang melemah industry Food and Baverages masih menjadi investasi baik dikalangan investor. Meskipun secara fenomena terjadi perubahan yang tidak menentu harga saham sektor Food and Baverages pada periode 2015-2017 sebagai akibat dari inflasi, kelesuan ekonomi dan kenaikan sinyal suku bunga Amerika Serikat, namun sektor ini masih memberi sinyal baik bagi para investor.

Saham adalah alat atau sarana investasi yang paling banyak diminati oleh para investor, karena saham mampu memberikan tingkat keuntungan yang menarik serta menjanjikan. Investor yang menginvestasikan sahamnya pada sekuritas, berperan penting terhadap good return dimasa sekarang maupun dimasa yang akan datang. Dalam melakukan transaksi saham dipasar modal, para investor harus teliti dalam mengambil sebuah keputusan, baik itu keputusan membeli, menjual maupun mempertahankan saham tersebut. Sebab itu, salah satu faktor yang harus dipertimbangkan dalam membuat dan 
mengambil keputusan adalah faktor harga saham. Semakin tinggi harga saham berarti semakin tinggi pula nilai suatu perusahaan, begitu pula sebaliknya. Faktor tersebut dipengaruhi oleh faktor eksternal dan faktor internal. Faktor internal yaitu faktor yang timbul dari dalam perusahaan, sedangkan faktor eksternal adalah faktor yang timbul dari luar perusahaan. biasanya faktor ini sulit untuk diatasi seperti adanya masalah-masalah yang berkaitan dengan ekonomi makro dan mikro.

\section{B. Rumusan Masalah}

Sesuai dengan latar belakang yang telah dikemukakan sebelumnya, maka penulis merumuskan beberapa permasalahan yang ingin di kaji lebih mendalam antara lain :

a. Apakah rasio likuiditas berpengaruh terhadap harga saham pada perusahaan Food and Baverages periode 20162019 ?

b. Apakah rasio solvabilitas berpengaruh terhadap harga saham pada perusahaan Food and Baverages periode 2016-2019?

c. Apakah rasio profitabilitas berpengaruh terhadap harga saham pada perusahaan Food and Baverages periode 2016-2019?

d. Apakah rasio Likuiditas, Solvabilitas, dan Profitabilitas secara simultan berpengaruh terhadap harga saham pada perusahaan Food and Baverages periode 2016-2019?

\section{Tujuan Penelitian}

Berdasarkan rumusan masalah yang dikemukakan di atas, maka tujuan penelitian ini adalah sebagai berikut:

a. Untuk mengetahui pengaruh rasio likuiditas terhadap harga saham pada perusahaan Food and Baverages periode 2016-2019.

b. Untuk mengetahui pengaruh rasio solvabilitas terhadap perusahaan Food and Baverages periode 2016-2019.

c. Untuk mengetahui pengaruh rasio profitabilitas terhadap harga saham pada perusahaan Food and Baverages periode 2016-2019.

d. Untuk mengetahui pengaruh rasio likuiditas, solvabilitas, dan profitabilitas secara simultan terhadap harga saham pada perusahaan Food and Baverages periode 2016-2019.

\section{LANDASAN TEORI}

\section{A. Lapoan Keuangan}

Menurut Standar Akuntansi Keuangan (SAK) dalam buku Wiratna (2019:1) laporan keuangan merupakan bagian dari proses pelaporan keuangan. Laporan keuangan yang lengkap terdiri dari neraca, laporan laba rugi, dan laporan perubahan posisi keuangan yang laporan lain serta materi penjelasan merupakan bagian integral dari laporan keuangan.

Sedangkan menurut Fahmi (2019:1) menyatakan suatu laporan keuangan (financial statement) akan menjadi bermanfaat untuk mengambil keputusan, apabila dengan informasi tersebut dapat diprediksi apa yang akan terjadi dimasa mendatang. Dengan mengolah lebih lanjut terkait laporan keuangan melalui proses perbandingan, evaluasi dan analisis trend, mampu memprediksi yang mungkin akan terjadi dimasa mendatang, sehingga disinilah laporan keuangan begitu diperlukan. Maksud dari laporan keuangan menunjukkan kondisi perusahaan saat ini dengan laporan keuangan pada tanggal tertentu (untuk neraca) dan periode tertentu (untuk laporan laba rugi)

Secara umum laporan keuangan adalah catatan informasi keuangan suatu perusahaan pada suatu periode akuntansi yang dapat digunakan untuk menggambarkan kinerja pada perusahaan tersebut. Tujuan laporan keuangan menurut Dwi (2019:3) laporan keuangan disusun dengan tujuan untuk menyediakan informasi menyangkut posisi laporan keuangan, serta kinerja dan posisi keuangan suatu perusahaan yang bermanfaat bagi sejumlah besar pemakai dalam pengambilan keputusan ekonomi. Informasi mengenai tersebut sangat diperlukan untuk dapat melakukan evaluasi atas kemampuan suatu perusahaan dalam menghasilkan kas .

Menurut Hery (2018:4) menyatakan tujuan keseluruhan dari laporan keuangan adalah untuk memberikan informasi yang berguna bagi investor dan kreditor dalam pengambilan keputusan investasi dan kredit. 


\section{B. Harga Saham}

Menurut Hartono (2017:200) menyatakan bahwa harga saham merupakan harga suatu saham yang dapat terjadi dipasar bursa pada saat tertentu yang ditentukan oleh pelaku pasar dan ditentukan oleh permintaan dan penawaran saham yang bersangkutan dipasar modal. Dengan kata lain, harga saham terbentuk dari supply dan demand atas saham tersebut. Supply dan demand terjadi karena banyak faktor baik yang sifatnya spesifik atas saham tersebut (kinerja perusahaan dan industri dimanapun perusahaan bergerak) maupun faktor yang sifatnya makro seperti kondisi makro Negara, sosial dan politik, serta rumor-rumor yang berkembang. Pengukuran dari variabel harga saham ini yaitu harga saham penutupan, sehingga dapat dituliskan sebagai berikut:

\section{Harga Saham $=$ Closing Price}

Saham adalah surat berharga yang diperjual belikan dipasar modal, ada banyak hal yang mempengaruhi naik turunnya harga saham suatu perusahaan baik itu faktor internal maupun faktor eksternal, dalam bukunya Fahmi (2019:57) mengatakan bahwa ada beberapa kondisi dan situasi yang menentukan harga saham itu akan mengalami fluktuasi, yaitu:

a. Kondisi mikro dan makro ekonomi, dengan kata lain kinerja perusahaan dan resiko yang dihadapi dipengaruhi oleh faktor mikro ekonomi dan makro ekonomi, yang meliputi tingkat inflasi, peraturan perpajakan, kurs valuta asing, tingkat bunga pinjaman dan sebagainya.

b. Pergantian direksi, akan mempengaruhi keputusan investor dalam menanamkan investasinya dalam perusahaan, hal ini dikaitkan dengan kinerja sebelumnya dan harapan investor terhadap prospek kerja dimasa mendatang.

c. Kinerja perusahaan yang terus mengalami penurunan dalam setiap waktunya.

d. Resiko sistematis yaitu resiko yang disebabkan oleh faktor-faktor secara bersamaan mempengaruhi harga saham dipasar modal. Resiko ini ada karena adanya perubahan ekonomi secara makro atau politik seperti kebijakan fiksal pemerintah, pergerakan tingkat suku bunga, nilai tukar mata uang, dan inflasi.

e. Efek dari psikologi pasar yang ternyata mampu menekan kondisi teknikal seperti adanya sentimen pembeli dan penjual pada waktu-waktu tertentu, misalnya berkurangnya kepercayaan investor pada saat kondisi ekonomi seperti situasi pandemik saat ini.

Selain itu menurut beberapa peneliti, harga saham di pengaruhi oleh beberapa faktor diantarnya sebagai berikut.

1. Rasio likuiditas juga dapat mempengaruhi harga saham dikarenakan sebagian besar investor melihat perusahaan dari kemampuannya dalam membayar kewajiban lancarnyaa, jika kewajiban lancarnya dapat dipenuhi sudah pasti perusahaan tersebut dikatakan tidak memiliki masalah keuangan.

2. Rasio solvabilitas merupakan faktor yang mempengaruhi harga saham dimana nilai solvabilitas yang tinggi akan membuat investor berfkir kembali dalam menamkan uangnya, dikarenakan perusahaan tersebut bergantung kepada pihak ketiga dalam menjalankan kegiatan perusahaan.

3. Rasio profitabilias juga merupakan salah satu faktor yang mempengaruhi harga saham dimana seorang investor melihat perusahaan dari cara memanfaatkan aset yang dimiliki untuk menghasilkan sebuah keuntungan sehingga akan menaikkan harga saham dipasar modal.

\section{Rasio Likuiditas}

Rasio likuiditas adalah rasio yang digunakan untuk mengukur kemampuan perusahaan dalam menjamin kewajibankewajiban lancarnya secara cepat tepat waktu, Fahmi (2019:121). Sedangkan menurut Kariyoto (2017) Likuiditas adalah kemampuan suatu perusahaan untuk memenuhui kewajiban keuangannya dalam jangka pendek atau pada waktu tagih.

Maka dari itu, rasio likuiditas merupakan kemampuan perusahaan dalam memenuhi kewajiban jangka pendeknya. Perusahaan yang mampu memenuhi kewajiaban pada tepat waktu, berarti perusahaan tersebut dalam keadaan likuid, apabila perusahaan tersebut mempunyai alat pembayaran atau aktiva lancar yang lebih besar dari hutang. Sebaliknya jika perusahaan tidak bisa memenuhi kewajiban jangka pendeknya dapat dikatakan bahwa perusahaan tersebut sedang tidak likuid. Menurut Kasmir (2018:132) bahwa tujuan dan manfaat yang dapat dirangkum dari hasil ratio likuiditas:

a. Untuk mengukur kemampuan perusahaan membayar kewajiban atau utang yang segera jatuh tempo pada saat ditagih. 
b. Untuk mengukur kemampuan perusahaan membayar kewajiban jangka pendek dengan aktiva lancar secara keseluruhan.

c. Untuk mengukur kemampuan perusahaan membayar kewajiban jangka pendek dengan aktiva lancar tanpa memperhitungkan persedian atau piutang. Dalam hal ini aktiva lancar dikurangi persedian dan utang yang dianggap likuiditasnya lebih rendah.

d. Untuk mengukur dan membandingkan antara jumlah persedian yang ada dengan modal kerja perusahaan.

e. Untuk mengukur seberapa besar uang kas yang tersedia untuk membayar utang.

\section{Current Ratio}

Menurut Hanafi (2015:37) Current ratio menjadi alat ukur untuk likuiditas dengan mengukur kemampuan likuiditas jangka pendek perusahaan dan melihat besarnya aktiva lancar relatif terhadap hutang lancarnya. Perhitungan rasio lancar dapat diartikan untuk mengetahui tingkat kemampuan perusahaan dalam memenuhi kewajiban lancarnya yang dimana jenis aktiva tersebut dapat diukur dengan kas dalam periode tertentu. Rasio lancar menunjukkan efisiensi siklus operasi perusahaan atau kemampuannya mengubah pruduk menajdi uang tunai, rasio ini merupakan salah satu analisisis rasio likuiditas juga dikenal sebagai analisis modal kerja/Working Capital Ratio. Menurut Gitman dan Zutter (2015:119) untuk mengukur current ratio dapat dirumuskan sebagai berikut:

$$
\text { Current Ratio }=\frac{\text { Aset Lancar }}{\text { Kewajiban Lancar }} \times 100 \%
$$

\section{Rasio Solvabilitas}

Untuk mengetahui besarnya hutang yang dimiliki perusahaan dan melakukan perbandingan dengan total aktivanya, dapat digunakan rasio solvabilitas. Menurut Hery (2018:190) rasio solvabilitas merupakan rasio yang digunakan untuk mengukur sejauh mana aset perusahaan dibiayai dengan utang. Dengan kata lain rasio solvabilitas merupakan rasio yang digunakan untuk mengukur seberapa besar beban utang yang harus ditanggung perusahaan dalam rangka pemenuhan aset. solvabilitas juga faktor yang perlu diperhatikan ketika perusahaan dihadapkan dengan situasi untuk melakukan pinjaman atau tidak kepada kreditor. Perusahaan yang memiliki hutang dengan jumlah yang besar belum tentu dapat dikatakan perusahaan tersebut tidak sehat, oleh karena itu besarnya jumlah hutang harus dikendalikan dengan mengalokasikan dana yang didapatkan ke pembiayaan yang diperlukan. Perusahaan memiliki kemampuan untuk melakukan pinjaman akan terlihat pada solvabilitas. Perusahaan yang tidak mempunyai laverage berarti menggunakan modal sendri 100\%. Menurut Hery (2018:192) berikut adalah tujuan dan manfaat rasio silvabilitas:

a. Untuk mengetahui posisi total kewajiban perusahaan kepada kreditor.

b. Untuk mengetahui posisi kewajiban jangka panjang perusahaan terhadap jumlah modal yang dimiliki perusahaan.

c. Untuk menilai seberapa besar aset perusahaan dibiayai oleh utang dan modal.

d. Untuk mengukur berapa bagian dari setiap rupiah aset yang dijadikan jaminan utang bagi kreditor.

\section{Debt To Equity Ratio (DER)}

Rasio solvabilitas yang digunakan dalam penelitian ini adalah Debt To Equity Ratio (DER) yaitu rasio yang digunakan untuk menilai utang dengan ekuitas. Yang artinya kewajiban yang dibayar lebih rendah dari pada modal sehingga beban yang ditanggung tidak bertambah. Apabila rasionya tinggi, artinya pendanaan utang semakin banyak, maka semakin sulit bagi perusahaan untuk memperoleh tambahan pinjaman karena dikhawatirkan perusahaan tidak mampu menutupi utang-utangnya dengan aset yang dimilikinya, Kasmir (2016:157).

Sedangkan menurut sukmawati (2017:50) Debt To Equity Ratio merupakan pengukur persentase liabilitas pada struktur modal perusahaan. Rasio ini penting untuk mengukur risiko bisnis perusahaan yang semakin meningkat dengan jumlah liabilitas. Rasio ini juga menjadi alat perbandingan antara jumlah dana yang disediakan oleh kreditor dengan jumlah dana yang berasal dari pemilik perusahaan. 

berikut.

Menurut Gitman dan Zutter (2015:126) Debt To Equity Ratio dapat dihitung dengan menggunakan rumus sebagai

$$
\text { DER }=\frac{\text { Total Kewajiban }}{\text { Total Modal }} \times 100 \%
$$

\section{E. Rasio Profitabilitas}

Brigham dan Houston (2015:139) rasio profitabilitas adalah rasio yang mencerminkan hasil akhir dari seluruh kebijakan keuangan dan keputusan operasi. Rasio ini juga memberikan ukuran tingkat efektivitas manajemen suatu perusahaan. Hal ini ditunjukkan oleh laba yang dihasilkan dari penjualan dan pendapatan investasinya.

Sedangkan menurut Fahmi (2019:137) rasio ini melihat sejauh mana investasi yang telah ditanamkan mampu memberikan pengembalian keuntungan sesuai dengan yang diharapkan. Rasio ini juga disebut sebagai rasio rentabilitas, yang dimana merupakan salah satu jenis rasio keuangan yang sangat penting bagi investor karena secara langsung memberikan informasi terkait kinerja keuangan pada suatu emiten. Dengan demikian investor dapat melihat bagaimana prospek bisnis perusahaan dimasa mendatang. Menurut Hery (2018:227) berikut adalah tujuan dan manfaat rasio profitabilitas:

a. Untuk mengukur kemampuan perusahaan dalam menghasilkan laba selama periode tertentu.

b. Untuk menilai posisi laba perusahaan tahun sebelumnya dengan tahun sekarang.

c. Untuk menilai perkembangan laba dari waktu ke waktu.

d. Untuk mengukur seberapa jumlah laba bersih yang akan dihasilkan dari setiap rupiah dana yang tertanam dalam total aset.

e. Untuk mengukur margin laba kotor dan laba bersih atas penjualan bersih.

f. Untuk mengukur margin laba operasional atas penjualan bersih.

\section{Return On Asset}

Dalam penelitian ini proxi rasio profitabilitas yang digunakan adalah Return On Asset, merupakan rasio untuk mengukur keseluruhan efektifitas manajemen dalam menghasilkan keuntungan dengan aset yang ada, Gitman dan Zutter (2015:130). Sedangkan menurut Fahmi(2019:137) rasio ini mengkaji sejauh mana perusahaan mempergunakan sumber daya yang dimiliki untuk mampu memberikan laba atau ekuitas. Perusahaan dengan tingkat profitabilitas yang tinggi mampu memberikan return yang tinggi bagi para investor karena secara khusus meningkatkan harga saham nilai perusahaan dan bisa membayar tingkat persen bunga pokok pinjaman, (Pantow, Murma \& Trang.2015:10).

Return on asset merupakan bagian dari rasio Profitabilitas dimana dalam sebuah analisis laporan keuangan rasio inilah yang paling sering disoroti karena mampu menunjukkan keberhasilan suatu instansi dalam menghasilkan profit atau keuntungan. Aktiva atau aset yang dimaksud adalah seluruh kekayaan dari suatu perusahaan yang didapat dari modal pribadi atau dari modal luar (asing) yang telah dikelola perusahaan menjadi akitva-aktiva yang digunakan untuk kelangsungan hidup perusahaan, (Maharani, I Gusti \& Suardana, 2016). Menurut Gitman dan Zutter (2015:130) Return On Asset dapat dihitung menggunakan rumus sebagai berikut.

$$
\mathrm{ROA}=\frac{\text { Laba Bersih Setelah Pajak }}{\text { Total Aset }} \times 100 \%
$$




\section{F. Kerangka Pemikiran}

\section{Gambar 1. Kerangka Pemikiran}

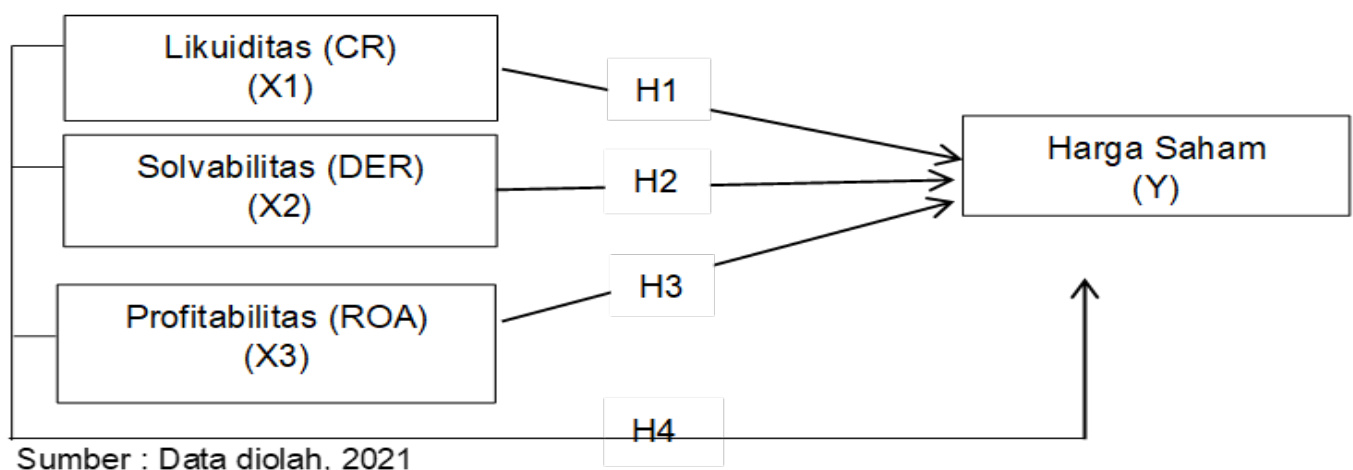

\section{G. Hipotesis}

Berdasarkan model kerangka penelitian diatas, maka dirumuskan sebuah hipotesis sebagai berikut:

a. Diduga rasio likuiditas (Current Ratio) berpengaruh terhadap harga saham perusahaan Food and Baverages.

b. Diduga rasio solvabilitas (Debt To Equity Ratio) berpengaruh terhadap harga saham perusahaan Food and Baverages.

c. Diduga rasio profitabilitas (Return On Asset) berpengaruh terhadap harga saham perusahaan Food and Baverages.

d. Diduga Current Ratio, Debt To Equity Ratio, dan Return On Asset secara simultan berpengaruh terhadap harga saham perusahaan Food and Baverges.

\section{METODE PENELITIAN}

\section{A. Lokasi Penelitian}

Penelitilian ini lilakukan pada industry Food and Beverage yang terdaftar di Bursa Efek Indonesia.

\section{B. Jenis dan Sumber Data}

Penelotoan ini mempergunakan dua jenis data yaitu data Kualitatif dan data Kuantitif. Namun pada peneitilian ini penulis hanya menggukakan data kualntitatif. Jadi data kualitatif yang digunakan dalam penelitian ini adalah nama perusahaan konsisten yang terdaftar dan melalporkan laporang keuangannya di Food and Baverage yang terdaftar di BEl periode 2016-2019.

Sumber data dalam penelitian ini adalah dara primer dan data sekunder. Data primer adalah sumber data secara langusng diperoleh atau diberikan peneliti sedangkan data sekunder adalah sumber yang tidak secra langsung diberikan kepada penelili. Sehingga pada penelitian ini peneliti hanya menggunakan data sekunder dikarekanak sumber data peneititiannya di download dari www.idx.co.id dan www.samahok.com

\section{Metode Analisis}

Metode analisis yang digunakan dalam penelitian ini adalah dengan melakukan pendekatan kuantitatif. Tahap awal dalam melakukan analisis adalah dengan melakukan analisis rasio keuangan. Karena Rasio Keuangan merupakan salah satu alat analisis keuangan yang sangat terkenal dan banyak sekali digunakan walaupun perhitungna rasio ini adalah operasi aritmatikan sederhana tetapi hasilnya tidak muda diniterprestasikan. Jadi ada tiga rasio yang digunakan dalam penelitian ini yaitu Rasio Lukuiditas yang diprosikan dengan Cuurent ratio, Rasio Solvabilitas yang diproksikan dengan Debt To Equity Ratio dan Profitabilitas yang diproksikan dengan Return on Asset. 


\section{HASIL DAN PEMBAHASAN}

\section{A. Analisis Data}

Di bawah ini peneliti akan menjelaskan hasil analisis data yang peneliti telah lakukan.

\section{Analisis Rasio Keuangan}

a. Rasio Lukuiditas

Likuiditas adalah perusahaan memiliki kemampuan untuk memenuhui kewajiban financialnya dalam jangka pendek atau pada waktu tagih. Current Ratio merupakan mengukur kemampuan perusahaan dalam memenuhi kewajiban jangka pendeknya. Untuk menghitung Current Ratio dapat digunakan dari aset lancar perusahaan dibagi dengan kewajiban perusahaan.

$$
\text { Current Ratio }=\frac{\text { Aset Lancar }}{\text { Kewajiban Lancar }} \times 100 \%
$$

Berikut ini adalah hasil perhitungan Current Ratio dari seluruh perusahaan:

Tabel. 1

Data Current Ratio

\begin{tabular}{|c|c|c|c|c|c|c|}
\hline \multirow{2}{*}{ NO } & \multirow{2}{*}{ KODE } & \multicolumn{4}{|c|}{ CR (\%) } & \multirow{2}{*}{ RATA-RATA } \\
\hline & & 2016 & 2017 & 2018 & 2019 & \\
\hline 1 & CEKA & 281,93 & 222,44 & 511,30 & 479,97 & 373.9100 \\
\hline 2 & DLTA & 760,39 & 863,78 & 719,83 & 805,05 & 787.2625 \\
\hline 3 & ICBP & 240,68 & 242,83 & 195,17 & 253,57 & 233.0625 \\
\hline 4 & INDF & 150,81 & 152,27 & 106,63 & 127,21 & 134.2300 \\
\hline 5 & MLBI & 67,95 & 82,57 & 77,84 & 73,19 & 75.3875 \\
\hline 6 & MYOR & 225,02 & 238.60 & 265,46 & 342,86 & 267.985 \\
\hline 7 & ROTI & 296,23 & 225,86 & 357,12 & 169,33 & 262.135 \\
\hline 8 & SKLT & 131,53 & 126,31 & 122,44 & 129,01 & 127.3225 \\
\hline
\end{tabular}

Sumber: Data sekunder diolah, 2021

Berdasarkan pada table 4.2 dapat diketahui bahwa data tertinggi dengan periode tahun 2016 - 2019 dimiliki oleh perusahaan PT. Delta Djakarta Tbk (DLTA) dengan nilai persentase antara $760,39 \%-805,05 \%$ dengan rata-rata Current Ratio sebesar $787,2625 \%$ hal ini dapat diartikan bahwa semakin tinggi nilai Current Ratio semakin baik perusahaan dalam melunasi kewajiban lancarnya, hal tersebut dapat membuat daya tarik investor untuk bergabung dengan perusahaan tersebut. Bagi pihak ketiga Current Ratio yang tinggi semakin baik pula keuangan perusahaan karena dinilai mampu dalam melunasi kewajiban jangka pendeknya. Sedangkan nilai terendah dari periode 4 tahun dimiliki oleh perusahaan PT. Multi Bintang Indonesia Tbk (MLBI) dengan nilai persentase 67,95\%-73,19\% dan rata-rata Current Ratio sebesar 75,3875\%, dapat diartikan bahwa perusahaan tersebut sedang berada dalam masalah keuangan, dan hal itu dapat mengurangi minat investor dalam bergabung.

\section{b. Rasio Solvabilitas}

Rasio solvabilitas merupakan rasio untuk menilai sejauh mana aset perusahaan dibiayai dengan utang. Debt To Equity Ratio, merupakan rasio yang digunakan untuk menilai hutang dengan ekuitas. Untuk menghitung nilai Debt To Equity Ratio digunakan dari total kewajiban dibagi dengan total modal.

$$
\text { DER }=\frac{\text { Total Kewajiban }}{\text { Total Modal }} \times 100 \%
$$


Berikut ini adalah hasil perhitungan Debt To Equity Ratio dari seluruh perusahaan:

Table 2. Data Debt To Equity Ratio

\begin{tabular}{|c|c|c|c|c|c|c|}
\hline \multirow{2}{*}{ NO } & \multirow{2}{*}{ KODE } & \multicolumn{4}{|c|}{ DER (\%) } & \multirow{2}{*}{ RATA-RATA } \\
\cline { 3 - 6 } & & $\mathbf{2 0 1 6}$ & $\mathbf{2 0 1 7}$ & $\mathbf{2 0 1 8}$ & $\mathbf{2 0 1 9}$ & \\
\hline 1 & CEKA & 60,60 & 54,22 & 19,69 & 23,14 & 39,41 \\
\hline 2 & DLTA & 18,32 & 17,14 & 18,64 & 17,50 & 17,90 \\
\hline 3 & ICBP & 56,22 & 55,57 & 51,35 & 45,14 & 52,07 \\
\hline 4 & INDF & 87,01 & 87,68 & 93,40 & 77,48 & 86,39 \\
\hline 5 & MLBI & 177,23 & 135,71 & 147,49 & 152,79 & 153,31 \\
\hline 6 & MYOR & 106,26 & 102,82 & 105,93 & 92,30 & 101,83 \\
\hline 7 & ROTI & 102,37 & 61,68 & 50,63 & 51,40 & 66,52 \\
\hline 8 & SKLT & 91,87 & 106,87 & 120,29 & 107,91 & 106,74 \\
\hline
\end{tabular}

Sumber: Data sekunder diolah, 2021

Berdasarkan pada table 4.4 dapat diketahui bahwa data tertinggi dengan periode tahun 2016-2019 dimiliki oleh perusahaan PT. Multi Bintang Indonesia Tbk (MLBI) dengan nilai persentase antara 177,23\%-152,79\% dengan rata-rata Debt To Equity Ratio sebesar $153,31 \%$. Hal ini akan menimbulkan dampak yang buruk terhadap kinerja perusahaan dikarenakan tingkat utang yang tinggi dan beban bunga yang semakin besar dapat mengganggu profit. Sedangkan nilai terendah dari periode 4 tahun dimiliki oleh perusahaan PT. Delta Djakarta Tbk (DLTA) dengan nilai persentase antara 18,32\%-17,50\% dan rata-rata Debt To Equity Ratio sebesar $17,90 \%$ yang berarti bahwa perusahaan tersebut memiliki dampak baik karena dapat menyebabkan tingkat pengembalian yang tinggi.

\section{c. Rasio Profitabilitas}

Rasio profitabilitas adalah rasio yang menunjukan hasil akhir dari semua kebijakan financial dan operation decision. Return On Asset digunakan untuk mengukur keseluruhan efektifitas manajemen dalam memperoleh keuntungan dengan aset yang ada. Return On Asset dapat dihitung dengan cara laba bersih dibagi dengan jumlah aset.

$$
\mathrm{ROA}=\frac{\text { Laba Bersih Setelah Pajak }}{\text { Total Aset }} \times 100 \%
$$

Berikut adalah hasil perhitungan Return On Asset dari seluruh perusahaan sebagai berikut:

Table 3. Data Return On Asset

\begin{tabular}{|c|c|c|c|c|c|c|}
\hline \multirow{2}{*}{ NO } & \multirow{2}{*}{ KODE } & \multicolumn{4}{|c|}{ ROA (\%) } & \multirow{2}{*}{ RATA-RATA } \\
\cline { 3 - 6 } & & $\mathbf{2 0 1 6}$ & $\mathbf{2 0 1 7}$ & $\mathbf{2 0 1 8}$ & $\mathbf{2 0 1 9}$ & \\
\hline 1 & CEKA & 17,51 & 7,71 & 7,93 & 15,47 & 12,16 \\
\hline 2 & DLTA & 21,25 & 20,87 & 22,19 & 22,29 & 21,65 \\
\hline 3 & ICBP & 12,56 & 11,21 & 13,56 & 13,85 & 12,80 \\
\hline 4 & INDF & 6,41 & 5,77 & 5,14 & 6,14 & 5,87 \\
\hline 5 & MLBI & 43,17 & 52,67 & 42,39 & 41,63 & 44,97 \\
\hline 6 & MYOR & 10,75 & 10,93 & 10,01 & 10,71 & 10,60 \\
\hline 7 & ROTI & 9,58 & 2,97 & 2,89 & 5,05 & 5,12 \\
\hline 8 & SKLT & 3,63 & 3,61 & 4,28 & 5,68 & 4,30 \\
\hline
\end{tabular}

Sumber: Data diolah, 2021 
Berdasarkan pada tabel 4.6 dapat diketahui bahwa data tertinggi dengan periode tahun $2016-2019$ dimiliki oleh perusahaan PT. Multi Bintang Indonesia Tbk (MLBI) dengan nilai persentase antara 43,17\%41,63\% dengan rata-rata Return On Asset sebesar 44,97\% yang berarti bahwa perusahaan mampu menghasilkan laba dari total aktiva yang dimilikinya. Sedangkan nilai terendah dari periode 4 tahun dimiliki oleh perusahaan PT. Sekar Laut Tbk (SKLT) dengan nilai persentase sebesar 3,63\%-5,68\% dan rata-rata Return On Asset sebesar 4,30\%, yang berarti bahwa perusahaan kurang mampu dalam memanfaatkan aktiva untuk menghasilkan profit yang tinggi.

\section{d. Harga Saham}

Harga saham yang digunakan pada penelitian ini adalah harga saham penutupan (closing price) per 31 desember pada setiap tahunnya. Data harga saham penutupun perusahaan Food and Baverages pada periode 2016-2019 dapat dilihat pada tabel berikut.

Tabel 4. Harga Saham Perusahaan Food and Baverages

\begin{tabular}{|c|c|c|c|c|c|}
\hline \multirow{2}{*}{ No } & \multirow{2}{*}{ Kode } & \multicolumn{4}{|c|}{ Harga Saham } \\
\cline { 3 - 6 } & & $\mathbf{2 0 1 6}$ & $\mathbf{2 0 1 7}$ & $\mathbf{2 0 1 8}$ & $\mathbf{2 0 1 9}$ \\
\hline 1 & CEKA & 1.350 & 1.290 & 1.375 & 1.670 \\
\hline 2 & DLTA & 5.000 & 4.590 & 5.500 & 6.800 \\
\hline 3 & ICBP & 8.575 & 8.900 & 10.450 & 11.150 \\
\hline 4 & INDF & 7.925 & 7.625 & 7.450 & 7.925 \\
\hline 5 & MLBI & 11.750 & 13.675 & 16.000 & 15.500 \\
\hline 6 & MYOR & 1.645 & 2.020 & 2.620 & 2.050 \\
\hline 7 & ROTI & 1.600 & 1.275 & 1.200 & 1.300 \\
\hline 8 & SKLT & 308 & 1.100 & 1.500 & 1.610 \\
\hline
\end{tabular}

Sumber: Data olah, 2021

Berdasarkan tabel 4.7 harga saham penutupan tertinggi pada perusahaan Food and Baverages periode 2016-2019 yaitu perusahaan PT. Multi Bintang Indonesia Tbk (MLBI) pada tahun 2018 sebesar 16.000. sedangkan untuk harga saham penutupan terendah selama periode penelitian dimiliki oleh perusahaan PT. Sekar Laut Tbk. (SKLT) pada tahun 2016 sebesar 308 saham.

\section{Analisis Statistik}

\section{a. Statistic Deskriptif}

Table 5

Statistic Descriptive

\begin{tabular}{|l|r|c|c|c|c|}
\hline & N & Minimum & Maximum & Mean & Std. Deviation \\
\hline HARGA SAHAM & 32 & 308 & 16000 & 5397.75 & 4671.588 \\
\hline CR & 32 & 67.95 & 863.78 & 280.6931 & 222.13083 \\
\hline DER & 32 & 17.14 & 177.23 & 78.0203 & 42.85448 \\
\hline ROA & 32 & 2.89 & 52.67 & 14.6816 & 13.04286 \\
\hline Valid N (listwise) & 32 & & & & \\
\hline
\end{tabular}

Sumber: Data diolah, 2021 

berikut:

Berdasarkan hasil uji statistik deskriptif yang ditunjukkan pada tabel 4.7 diatas, maka dapat dijelaskan sebagai

1) Harga Saham merupakan variabel dependen yang menunjukkan nilai terendah (Minimum) sebesar 308 , sedangkan nilai tertinggi (Maximum) sebesar 16000, dengan nilai rata-rata (Mean) sebesar 5397,75 dan standar deviasi (Std Deviation) sebesar 4671,588.

2) Current Ratio merupakan variabel independent yang menunjukkan nilai terendah (Minimum) sebesar 67,95, sedangkan nilai tertinggi (Maximum) sebesar 863,78, dengan nilai rata-rata (Mean) sebesar 280,6931 dan standar deviasi (Std Deviation) sebesar 222,13083.

3) Debt To Equity Ratio (DER) merupakan variabel independent yang menunjukkan nilai terendah (Minimum) sebesar 17,14, sedangkan nilai tertinggi (Maximum) sebesar 177,23, denagn nilai rata-rata (Mean) sebesar 78,0203 dan standar deviasi (std Deviation) sebesar 42,85448.

4) Return On Asset (ROA) merupakan variabel independent yang menunjukkan nilai terendah (Minimum) sebesar 2,89 sedangkan nilai tertinggi (Maximum) sebesar 52,67, dengan nilai rata-rata (Mean) sebesar 14,6816 dan standar deviasi (Std Deviation) sebesar 13,04286.

\section{b. Uji asumsi klasik}

Sebelum dilakukan uji hipotesis (uji $t$ dan uji f) terlebih dahulu dilakukan uji asumsi klasik, uji tersebut digunakan sebagai persyaratan statistik yang harus dipenuhi pada analisis regresi linear berganda. Uji asumsi klasik terdiri dari Uji Normalitas, Uji Multikolineritas, Uji Heterokekedastisitas, Uji Autokolerasi.

a) Uji Normalis

Uji Normalitas bertujuan untuk mengetahui apakah dalam model regresi, variabel pengganggu atau residual memiliki distribusi normal atau tidak. Dalam penelitian ini mendeteksi data berdistribusi normal atau tidak menggunkan uji statistik kolmogrov-Smirnov (K-S) dengan ketentuan jika nilai asymp. Sign. (2tailed) $>0,05$. Hasil perhitungan menunjukan data berdistribusi Normal dimana besarnya nilai KolmogrovSmirnov adalah 0,139 dan signifikannya sebesar 0,117 lebih besar dari 0,05

b) Uji multikolneritas

Uji Multikolineritas bertujuan untuk menguji apakah regresi ditemukan adanya kolerasi antar variabel bebas (independent). Multikolineritas dapat dilihat dari nilai tolerance dan lawanya Variance Inflation Factor (VIF). Hasil perhitungan menunjukan nilai tolerance dari Current Ratio (CR), Debt To Equity Ratio (DER), dan Return On Asset (ROA) lebih besar dari 0,10. nilai VIF dari Current Ratio (CR), Debt To Equity Ratio (DER), dan Return On Asset (ROA) lebih kecil dari 10,0. Berdasarkan hasil tersebut dapat disimpulkan bahwa tidak terjadi Multikolineritas, oleh karena itu hasil penelitian ini memenuhi syarat. Nilai tolerance yang umum dipakai adalah nilai tolerance $\leq 0,10$ atau sama dengan niali VIF $\leq 10,0$. Jika nilai VIF $<10,0$ maka tidak terjadi multikolineritas.

c) Uji heteroskedasititas

Berdasarkan grafik scatterplot diatas, terlihat bahwa titik-titik menyebar ke atas bawah pada angka 0 pada sumbu $Y$ dan tidak membentuk pola tententu yang jelas. Dengan demikian dapat disimpulkan bahwa regresi ini tidak terjadi heteroskedastisitas.

d) Uji autokorelasi

Uji Autokolerasi ini bertujuan menguji apakah dalam model regresi linear ada kolerasi antara kesalahan pengganggu pada periode $t$ dengan kesalahan pengganggu pada periode $\mathrm{t}-1$ (sebelumnya). Model regresi yang baik adalah tidak terjadi autokolerasi, sehingga dalam menguji ini digunakan uji Durbin Waston Test (DW Test) dengan hasil sebagai berikut. Diketahui nilai DW sebesar 0,582, nilai tersebut dibandingkan dengan tabel signifikansi $\alpha=5 \%$ dengan jumlah sampel $n=32$ dan jumlah variabel independent yaitu 3 $(\mathrm{K}=3)$. Berdasarkan tabel DW, maka diperoleh nilai dU sebesar 1,6505 dan nilai 4-dU adalah 2,3495, maka nilai DW 1,6505 >0,582 <2,3495. sehingga terjadi Autokolerasi. Selanjutnya hasil tersebut akan dilakukan uji dengan metode Chocrane-Orcut. Berikut hasil uji Autokolerasi setelah menggunakan metode ChocraneOrcut. Diketahui bahwa DW sebesar 1,706, nilai ini akan dibandingkan dengan dengan tabel signifikansi 
$5 \%$ dengan jumlah sampel $n=32$ dan jumlah variabel independenya yaitu $3(K=3)$. Berdasarkan tabel $D W$, maka diperoleh nilai dU sebesar 1,6505 dan nilai 4-dU adalah 2,3495, maka nilai DW 1,6505<1,706 < 2,3495 sehingga dapat disimpulkan bahwa pada model regeresi ini tidak terjadi Autokolerasi.

\section{Analisis Lineras Berganda}

Analisis linear berganda yaitu alat yang digunakan untuk memprediksi permintaan dimasa yang akan datang berdasarkan data masa lalu atau untuk mengetahui pengaruh dari variabel independen terhadap harga saham, dengan persamaan rumus sebagai berikut.

$$
Y=a+b 1 X 1+b 2 X 2+b 3 X 3+e
$$

Berdasarkan hasil perhitungan dengan munggunakan program statistic SPPS for windows release diperoleh hasil sebagai berikut ini.

\section{Tabel 6}

\section{Hasil Analisis Linear Berganda}

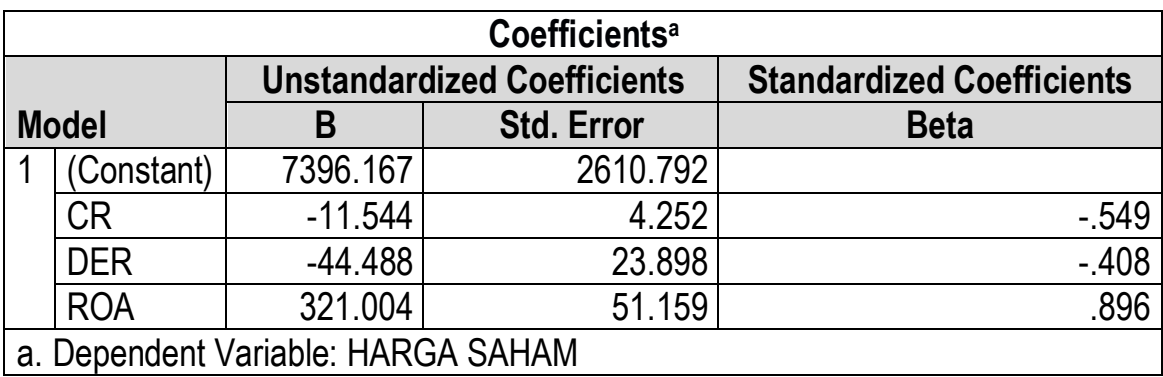

Sumber: Data diolah, 2021

Secara matemasil hasil analisis linear berganda dapat dituliskan berdasarkan rumus sebagai berikut.

$$
Y=7396,167 \alpha-11,544 \text { CR - 44,488 DER+ 321,004 ROA + e }
$$

Pada persamaan tersebut dapat ditunjukkan pengaruh Current Ratio (CR), Debt To Equity Ratio (DER), dan

Return On Asset (ROA) terhadap variabel dependen. Berikut penjelasan dari hasil regresi tersebut.

a. Nilai konstanta atau $\alpha=7396,167$, artinya tidak ada variabel bebas atau independen yang mempengaruhi harga saham, maka harga saham sebesar 7396,167.

b. Koefisien regresi Current Ratio (CR) atau $\beta 1=-11.544$ artinya bahwa setiap kenaikan Current Ratio sebesar 1 persen maka harga saham akan menurun sebesar 11,544 dengan asumsi variabel lainnya konstan.

c. Koefisien regresi Debt To Equity Ratio (DER) atau $\beta 2=-44,488$, artinya bahwa setiap kenaikan variabel Debt To Equity Ratio (DER) sebesar 1 persen, maka harga saham akan menurun sebesar 44,488 dengan asumsi variabel lainnya konstan.

d. Koefisien regresi Return On Asset (ROA) atau $\beta 3=321,004$, artinya bahwa setiap kenaikan variabel Return On Asset (ROA) sebesar 1 persen makan harga saham tersebut akan meningkat sebesar 321,004 dengan asumsi variabel lainnya konstan.

4. Uji Hipotesa

a. Uji Parsial (Uji t)

Berikut hasil uji beda test (Uji t) pengaruh likuiditas(Current Ratio), solvabilitas (Debt To Equity Ratio), dan Profitabilitas (Return On Asset) terhadap harga saham dengan menggunakan program statistik computer SPSS for Windows Release 25. 
Tabel 7. Hasil Uji Parsial (Uji t)

\begin{tabular}{|c|c|c|c|c|c|c|}
\hline \multirow{2}{*}{\multicolumn{2}{|c|}{ Model }} & \multicolumn{2}{|c|}{ Unstandardized Coefficients } & \multirow{2}{*}{$\frac{\text { Standardized Coefficients }}{\text { Beta }}$} & \multirow{2}{*}{$\mathrm{T}$} & \multirow{2}{*}{ Sig. } \\
\hline & & B & Std. Error & & & \\
\hline \multirow[t]{4}{*}{1} & (Constant) & 7396.167 & 2610.792 & & 2.833 & .008 \\
\hline & $\mathrm{CR}$ & -11.544 & 4.252 & -.549 & -2.715 & .011 \\
\hline & DER & -44.488 & 23.898 & -.408 & -1.862 & .073 \\
\hline & ROA & 321.004 & 51.159 & .896 & 6.275 & .000 \\
\hline
\end{tabular}

Sumber: Data diolah, 2021

Berikut penjelasan masing-masing variabel bebas berdsarkan hasil uji t.

a. Nilai signifikan current ratio sebesar 0,011 lebih kecil dari tingkat signifikasi $\alpha=5 \%$, hal ini menunjukkan bahwa Current Ratio (CR) berpengaruh negative dan signifikan terhadap harga saham pada perusahaan Food and Baverages yang terdaftar di Bursa Efek Indonesia periode 2016-2019, yang berarti bahwa jika Current Ratio meningkat, maka harga saham akan turun. Sehingga hipotesis diduga rasio likuiditas (Current Ratio) berpengaruh terhadap harga saham diterima.

b. b. Nilai signifikan Debt To Equity Ratio (DER) sebesar 0,073 lebih besar dari tingkat signifikansi a= $5 \%$, hal ini menunjukkan bahwa Debt To Equity Ratio (DER) tidak berpengaruh terhadap harga saham pada perusahaan Food and Baverages yang terdaftar di Bursa Efek Indonesia periode 2016-2019. Sehingga hipotesis rasio solvabilitas (Debt To Equity Ratio) berpengaruh terhadap harga saham ditolak.

c. Nilai signifikan Return On Asset (ROA) sebesar 0,000 lebih kecil dari tingkat signifikansi $\alpha=5 \%$, hal ini menunjukkan bahwa Return On Asset (ROA) berpengaruh positif dan signifikan terhadap harga saham pada perusahaan Food and Baverages yang terdaftar di Bursa Efek Indonesia periode 2016-2019, yang berarti bahwa jika return on asset meningkat, maka harga saham akan meningkat. Sehingga hipotesis diduga rasio profitabilitas berpengaruh terhadap harga saham diterima.

\section{b.Uji Simultan (Uji f)}

Berikut hasil uji simultan (Uji f) pengaruh likuiditas(Current Ratio), solvabilitas (Debt To Equity Ratio), dan Profitabilitas (Return On Asset) terhadap harga saham secara bersama-sama. dengan menggunakan program statistik komputer SPSS for Windows Release 25.

Tabel 8. Hasil Uji Simultan (uji F)

\begin{tabular}{|l|r|r|r|r|c|}
\hline \multicolumn{7}{|c|}{ ANOVA $^{\mathrm{a}}$} \\
\hline Model & \multicolumn{1}{|c|}{ Sum of Squares } & \multicolumn{1}{c|}{ df } & Mean Square & F & Sig. \\
\hline Regression & 431809202.376 & 3 & 143936400.792 & 16.468 & $.000^{\mathrm{b}}$ \\
\hline Residual & 244726499.624 & 28 & 8740232.129 & & \\
\hline Total & 676535702.000 & 31 & & & \\
\hline a. Dependent Variable: HARGA SAHAM & & & \\
\hline b. Predictors: (Constant), ROA, CR, DER \\
\hline
\end{tabular}

Sumber: Data diolah, 2021

Berdasarkan hasil perhitungan ditunjukkan pada tabel 4.15 diperoleh nilai signifikan sebesar 0,000. jika dibandingkan dengan tingkat signifikansi $\alpha=5 \%$ maka $0,000<0,05$. Hal ini dapat disimpulkan bahwa ada pengaruh secara simultan antara variabel likuiditas (Current Ratio), solvabilitas (Debt To Equity Ratio), dan profitabilitas (Return On Asset) terhadap harga saham pada perusahaan Food and Baverage yang terdaftar di Bursa Efek Indonesia periode 2016-2019 Bursa Efek Indonesia Periode 2016-2019. Sehingga H4 diterima. 


\section{c. Uji Koefisien Determinasi}

Koefisien determinasi menggambarkan kemampuan model menjelaskan variabel dependen. Nilai koefisien determinasi atau $\mathrm{R}^{\wedge} 2$ adalah antar 0 (nol) dan 1 . Model yang baik akan menghasilkan $\mathrm{R}^{\wedge} 2$ yang tinggi, setiap tambahan variabel independen akan meningkatkan $\mathrm{R}^{\wedge} 2$ walaupun tambahan tersebut tidak signifikan (Ratna, 2019:81-82).

Hasil ditabel 9 menunjukkan besarnya koefisien determinasi sebesar 0,638, menunjukkan jika likuiditas (Current Ratio), solvabilitas (Debt To Equity Ratio), dan profitabilitas (Return On Asset) secara bersama menjelaskan variabel dependen sebesar $63,8 \%$, sedangkan sisanya $36,2 \%$ dipengaruhi oleh variabel diluar penelitian ini.

Tabel 9. Hasil Uji Koefisien Determinasi

\begin{tabular}{|l|c|c|c|c|}
\hline Model & $\mathrm{R}$ & R Square & $\begin{array}{c}\text { Adjusted R } \\
\text { Square }\end{array}$ & $\begin{array}{c}\text { Std. Error of the } \\
\text { Estimate }\end{array}$ \\
\hline 1 & $.799 \mathrm{a}$ & .638 & .600 & 2956.388 \\
\hline \multicolumn{2}{|l|}{ a. Predictors: (Constant), ROA, CR, DER } \\
\hline \multicolumn{2}{|l}{ b. Dependent Variable: HARGA SAHAM } \\
\hline
\end{tabular}

Sumber: Data diolah, 2021

\section{B. Pembahasan hasil Analisis Data}

Berdasarkan hasil uji statistik diatas maka pembahasan yang dapat dikemukakan dalam penelitian ini adalah sebagai berikut:

\section{Pengaruh Lukiditas terhadap harga saham}

Hasil penelitian ini menunjukkan bahwa rasio likuiditas yang diproksikan dalam current ratio berpengaruh negative dan signifikan terhadap saham. Hal ini berdasarkan hasil uji parsial (uji t) dengan nilai t hitung sebesar (2.715) dengan tingkat signifikansi 0,011 lebih kecil dari 0,05, yang artinya semakin meningkat Current Ratio (CR) maka harga saham akan menurun. Likuiditas adalah kemampuan suatu perusahaan untuk memenuhui kewajiban keuangannya dalam jangka pendek atau pada waktu ditagih. Jika nilai Likuiditas tinggi bisa dikatakan bahwa perusahaan tidak mendapatkan kendala dalam melunasi utang jangka pendek, untuk menyakinkan kreditur dalam menentukan keputusan pinjaman perusahaan.

Likuiditas yang dihitung menggunakan Current Ratio (CR) memiliki hubungan yang signifikan terhadap harga saham. Current Ratio (CR) adalah rasio yang digunakan untuk mengetahui kemampuan perusahaan dalam melunasi kewajiban jangka pendeknya. Current Ratio (CR) dapat diperoleh dengan membagi aktiva lancar dengan kwajiban lancar. Current Ratio (CR) yang tinggi menunjukkan kondisi perusahaan yang sehat. Hal ini disebabkan perusahaan yang likuid karena memiliki aset lancar yang lebih besar dibandingkan kewajiban lancarnya, sehingga perusahaan mampu melunasi kewajibannya, hal tersebut dapat membuat investor tertarik untuk menanamkan sahamnya karena melihat kinerja perusahaan yang baik dan dapat memberikan dampak positif sehingga menjadikan harga saham akan naik dipasar modal. Dari sebagian besar perusahaan, Current Ratio (CR) adalah hal yang sangat penting karena berhubungan dengan pihak luar terutama kreditur.

Hasil penelitian ini sejalan dengan penelitian yang dilakukan oleh Dwi (2018) yang membuktikan bahwa Current Ratio berpengaruh terhadap saham, dan didukung oleh penelitian Rosayana, Paramita dan Mimin (2020) yang membuktikan bahwa Current Ratio berpengaruh signifikan terhadap harga saham.

\section{Pengaruh Solvabilitas terhadap Harga Saham}

Hasil penelitian ini menunjukkan bahwa rasio solvabilitas yang diproksikan dalam Debt To Equity Ratio tidak berpengaruh signifikan terhadap saham pada perusahaan food and baverage periode 2016-2019. Debt To Equity Ratio (DER) merupakan ukuran yang umum digunakan untuk mengukur suatu laverage perusahaan. Debt To Equity Ratio (DER) dapat diperoleh dari membagi total kewajiban dan total modal. Debt To Equity Ratio (DER) yang tinggi 
mengindikasikan bahwa perusahaan tersebut lebih banyak menggunakan dana dari pihak ketiga, yaitu kreditur yang berarti bahwa besarnya hutang yang dimiliki perusahaan menjadikan tingginya resiko yang akan didapat oleh para investor, hal ini memiliki dampak yang buruk terhadap keuntungan perusahaan dikarenakan tingkat utang yang tinggi dan beban bunga yang semakin besar mengurangi profit yang menyebabkan harga saham menurun. Penelitian ini sejalan dengan penelitian yang dilakukan oleh Sopyan dan Perkasa (2019) yang menunjukkan hasil Debt To Equity Ratio (DER) tidak berpengaruh signifikan terhadap harga saham. Selanjutnya diperkuat dengan penelitian Vera, Bernhard, dan Arazi (2016) dengan judul Pengaruh Current Ratio, Debt To Equity Ratio, dan Net Profit Margin Terhadap Harga Saham Perusahaan Food and Baverages yang Terdaftar di BEI Periode 2013-2015 yang menyatakan solvabilitas (Debt To Equity Ratio) tidak berpengaruh secara signifikan terhadap harga saham dikarenakan tingginya Debt To Equity Ratio.

\section{Pengaruh Profitabilitas terhadap harga saham}

Hasil penelitian ini menunjukkan bahwa rasio profitabilitas (Return On Asset) berpengaruh positif dan signifikan terhadap harga saham pada perusahaan food and baverage periode 2016-2019 dengan t hitung sebesar 6,275 dengan hasil signifikan 0,000, yang artinya jika Return On Asset naik, maka harga saham juga meningkat.

Rasio profitabilitas merupakan rasio yang mencerminkan hasil akhir dari seluruh kebijakan keuangan dan keputusan operasi atau dengan kata lain mengukur tingkat kemampuan perusahaan menggunakan aktiva untuk memperoleh laba setelah pajak. Profitabilitas dihitung dengan menggunakan Return On Asset (ROA) yang mana rasio ini menggambarkan sejauh mana kemampuan aset-aset yang dimiliki perusahaan bisa menghasilkan laba. Return On Asset (ROA) dapat diperoleh dari laba setelah pajak dan total aktiva. Semakin tinggi nilai Return On Asset (ROA) menunjukkan bahwa semakin efektif dalam memanfaatkan aktiva untuk menghasilkan laba bersih setelah pajak. Hal ini dapat meningkatkan daya tarik perusahaan kepada investor dipasar modal, dengan demikian Return On Asset akan berpengaruh terhadap harga saham. Jika nilai laba setelah pajak dan total aktiva tetap dapat menunjukkan kondisi keuangan yang bagus.

Penelitian ini sejalan dengan penelitian yang dilakukan oleh Rosayana, Paramita dan Mimin (2020) yang membuktikan bahwa variabel Return On Asset (ROA) berpengaruh signifikan terhadap harga saham, dan selanjutnya didukung oleh penelitian Rukmini dan Hadi (2020) membuktikan bahwa Return On Asset (ROA) berpengaruh signifikan terhadap harga saham.

\section{Pengaruh Likuiditas, Solvabilitas, Dan Profitabilitas Secara Simultan Terhadap Harga Saham}

Hasil penelitian ini menunjukkan bahwa secara simultan didapat bahwa variabel likuiditas, solvabilitas dan profitabilitas berpengaruh signifikan terhadap harga saham perusahaan food anad baverage periode 2016-2019.

Likuiditas yang dihitung dengan Current Ratio dapat peroleh dengan membagi aktiva lancar dengan kewajiban lancar. Solvabilitas yang dihitung dengan Debt To Equity dapat diperoleh dengan membagi total kewajiban dan total modal, sedangkan Profitabilitas yang dihitung dengan menggunakan Return On Asset dapat diperoleh dengan laba bersih setelah pajak dibagi total aktiva. Jika aset lancar, total modal serta laba bersih dari penjualan meningkat dengan asumsi bahwa nilai utang yang dimiliki perusahaan rendah maka perusahaan tersebut menunjukkan kondisi keuangan yang sehat. Artinya bahwa jika nilai likuiditas tinggi sudah dapat dipastikan bahwa perusahaan tersebut mampu melunasi jangka pendek, dan jika perusahaan dalam kondisi Debt To Equity Ratio yang normal atau rendah tentunya perusahaan melakukan kegiatan keseluruhan tidak bergantung oleh pihak ketiga. Hal ini mampu menyakinkan para investor tertarik untuk menanamkan modalnya sehingga perusahaan akan memperoleh keuntungan atau profit dan dapat memakmurkan para investornya.

Penelitian ini sejalan dengan penelitian yang dilakukan oleh Rosayana, Paramitha dan Mimin (2020) yang membuktikan bahwa secara simultan variabel likuiditas (Current ratio), solvabilitas (Debt To Equity Ratio), dan profitabilitas $(\mathrm{R})$ berp Return On Asset ngaruh signifikan terhadap harga saham. 


\section{PENUTUP}

\section{A. Simpulan}

Beberapa kesimpulan dari penelitian ini dapat dijelaskan sebagai berikut:

1. Variabel likuiditas yang diproksikan kedalam Current Ratio (CR) pada penelitian ini berpengaruh negative dan signifikan terhadap harga saham pada perusahaan Food and Baverages yang terdaftar di Bursa Efek Indonesia Periode 2016-2019 yang berarti jika current ratio meningkat maka harga saham akan menurun.

2. Variabel solvabilitas yang diproksikan kedalam Debt To Equity Ratio (DER) pada penelitian ini tidak berpengaruh terhadap harga saham pada perusahaan Food and Baverages yang terdaftar di Bursa Efek Indonesia Periode 20162019.

3. Variabel profitabilitas yang diproksikan kedalam Return On Asset (ROA) pada penelitian ini berpengaruh positif dan signifikan terhadap harga saham pada perusahaan Food and Baverages yang terdaftar di Bursa Efek Indonesia Periode 2016-2019 yang berarti bahwa jika Return On Asset meningkat maka harga saham juga akan meningkat .

4. Variabel likuiditas, solvabilitas, dan profitabilitas secara simultan pada penelitian ini berpengaruh signifikan terhadap harga saham pada perusahaan Food and Baverages yang terdaftar di Bursa Efek Indonesia Periode 2016-2019.

\section{B. Saran}

Berdasarkan kesimpulan di atas, maka penulis memberikan saran dalam penelitian ini antara lain:

1. Bagi investor, dalam mengambil keputusan berinvestasi saham pada peruashaan manufaktur sektor food and baverages sebaiknya memperhatikan kinerja keuangan perusahaan melalui rasio-rasio keuangan memiliki pengaruh secara signifikan terhadap harga saham.

2. Bagi perusahaan, sebaiknya perlu memperhatikan dan meningkatkan kinerja keuangan agar perusahaan dapat memaksimalkan profit sehingga dapat manaikkan harga saham dan menggunakan beban atau biaya secara efektik dan efisien karena salah satu kemajuan persahaan ada pada kinerja perusahaan.

3. Bagi penulis, sebaiknya menambahkan jumlah variabel penelitian selain Current Ratio, Debt To Equity Ratio dan Return On Asset, memperbanyak sampel perusahaan, dan periode penelitian yang digunakan ditambah dengan data yang terbaru sehingga menghasilkan informasi yang lebih mendukung. 


\section{DAFTAR PUSTAKA}

Aryani, dan Zulkifli.2016 Pengaruh Rasio Profitabilitas Terhadap Harga Saham Pada Perusahaan Industry Logam Dan Sejenisnya Yang Terdaftar di BEl Tahun 2007-2011. Jurnal Akuntansi Politeknik Sekayu (ACSY). Vol.4, No.1, Hal.23-31.

Brigham, E. F. \& Houston, J. F.(2015). Dasar-Dasar Manajemen Keuangan . Edisi 11. Buku 1. Jakarta: Salemba Empat.

Dwi, Prastowo. 2019. Analisis Laporan Keuangan Konsep dan Aplikasi. Yogyakarta: UPP STIM YKPN.

Dwi. 2018. Pengaruh Current Ratio Dan Debt To Equity Ratio Terhadap Harga Saham Perusahaan Food And Baverage Yang Terdaftar Di BEl Periode 2013-2017. Jurnal Riset Akuntansi Terpadu. Vol.12 No.1. Hal.144-166.

Fahmi, Irham.2019. Analisis Laporan Keuangan. Bandung: Alfabeta.

Fitri, S. A. 2016. Pengaruh Kinerja Keuangan Terhadap Harga Saham Perusahaan Food And Baverage Di BEl. Jurnal IImu dan Riset Manajemen.

Gitman, Lawrence J. and Chad J. Zutter.2015. Principles of Managerial Finance, Fourteenth Edition. United States : Pearson Education.

Hanafi, Mamduh M. 2015. Manajemen Keuangan. Cetakan Kedelapan. Yogyakarta: BPFE-Yogyakarta.

Hartono, Jogiyanto.2017. Teori Portofolio dan Analisis Investasi. Edisi Kesebelas, Cetakan Kedua. Yogyakarta:BPFE.

Hery. 2015. Analisis Laporan Keuangan. CAPS (Center for Academic Publishing Service). Yogyakarta.

Hery. 2018. Analisis Laporan Keuangan. Jakarta: PT Gramedia Indonesia.

Kariyoto. 2017. Analisis Laporan Keuangan. Cetakan Pertama. UB Press. Malang.

Kasmir. 2016. Analisis Laporan Keuangan. Jakarta: PT Raja Grafindo Persada.

Kasmir.2019.Analisis Laporan Keuangan. Jakarta: PT. Raja Grafindo Persada.

Oktaviani, S., Dahlia K (2017). Pengaruh Likuiditas, Profitabilitas, Dan Solvabilitas Terhadap Harga Saham (Studi Kasus Perusahaan Perbankan Yang Terdaftar Di BEI). Jurnal Akuntansi.77-89.

Pantow, Mawar Sharon R., Sri Murni, Ivan Trang. (2015). Analisis Pertumbuhan Penjualan, Ukuran Perusahaan, Return On Asset, dan Struktur Modal Terhadap Nilai Perusahaan Yang Tercatat Di Indeks LQ 45. Jurnal riset ekonomi, manajemen, bisnis dan akuntansi. Hal.961-971.

Ratna Nyoman Kutha 2019. Teori, Metode, Dan Teknik. Yogyakarta: Pustaka Pelajar.

Rosayana Diah, Paramitha dan Mimin. 2020. Pengaruh Profitabilitas, Likuiditas, Dan Ukuran Perusahaan Terhadap Harga Saham Perusahaan Manufaktur Yang Terdaftar Di BEI (Studi Kasus Sub Sektor Makanan Dan Minuman Periode 2015-2017), Jurnal Of Acounting . E-ISSN: 2715-8586. 
Ryan, Filbert. 2018. Trading Vs Investing. Elex Media Komputindo:Jakarta.

sanjaya, T. et al. 2015. Pengaruh Return On Equity, Debt Ratio, Debt To Equity Ratio, Earning Per Share Terhadap Harga Saham Studi Pada Perusahaan Food And Baverage Yang Terdaftar Dibursa Efek Indonesia Periode 2011-2015. Jurnal akuntansi bisnis. Vol 23 No 1.23

Sanusi, Anwar. (2011). Metode Penelitian Bisnis. Jakarta: Salemba Empat.

Siti, Khoiriyah.2018. Pengaruh Return On Asset (ROA), Return On Equity (ROE), Net Profit Margin(NPM) Dan Earing Per Share (EPS) Terhadap Harga Saham Pada Perusahaan Indeks Lq45 Yang Terdaftar di BEl periode2013-2016. Simki.unpkediri.ac.id

Sopyan dan Perkasa, D.H. 2019. Pengaruh Bevt To Equity Ratio, Return On Asset Dan Price Earning Ratio Terhadap Harga Saham Pada Subsektor Makanan Dan Minuman Yang Terdaftar Di Bursa Efek Indonesia Tahun 2012-2016. Jurnal IImu Manajemen Terapan, Vol 1 Issue 2, November 2019, E-ISSN:2686-4024 dan P-ISSN: 26865246.DOI:10.31933/JIMT

Sugiyono (2015). Metode Penelitian Kombinasi. Bandung: alfabeta.

Sugiyono. 2019. Metode Penelitian Kuantitatif, Kualitatif, dan R\&D. edisi kesatu. Cetakan ke-1. Bandung: Alfabeda.

Sujarweni, v. wiratna. 2017. Analisis Laporan Keuangan Teori, Aplikasi \& Hasil Penelitian. Yogyakarta: Pustaka Baru Press.

Sujarweni, v. wiratna. 2019. Analisis Laporan Keuangan Teori, Aplikasi. Edisi kesepuluh, jilid 1. Jakarta: PT Indeks.

Sukamulja, Sukmawati. (2017). Pengantar Pemodelan Bisnis Dan Ekonomi. Jakarta: Penerbit Andi.

Suwandi,.2017. Pengaruh Profitabilitas Terhadap Harga Saham Perusahaan Manufaktur Sektor Makanan Di BEI Tahun 20142015. Jurnal Akuntasi dan Pajak. Vol 18 No 01.pISSN: 1412-629X, pISSN: 2579-3055. Doi: 10.29040/jap.v18i01.89.

Syofian, Siregar. 2017. Metode Penelitian Kuantitatif. Cetakan Keempat. Jakarta: Kencana.

Tumandung, Murni dan Bramuli.2017. Analisis Pengaruh Kinerja Keuangan Terhadap Harga Saham Pada Perusahaan Maknan Dan Minuman Yang Terdaftar BEI Periode 2011-2015. Jurnal EMBA.Vol5 No 2.1730. ISSN 2303-1174.

Vera, Bernhard, Arrazi. (2016). Pengaruh Current Ratio, Debt To Equity Ratio, Dan Net Profit Margin Terhadap Harga Saham Perusahaan Food And Baverages Yang Terdaftar di BEI Periode 2013-2015. ISSN 2303-1174.

www.idx.co.id,

www.samahok.com 